\title{
Effect of contrasting crop rotation systems on soil chemical and biochemical properties and plant root growth in organic farming: First results
}

\author{
Elga Monaci, Serena Polverigiani, Davide Neri, Michele Bianchelli, Rodolfo Santilocchi, \\ Marco Toderi, Paride D’Ottavio, Costantino Vischetti
}

Department of Agricultural, Food and Environmental Sciences, Università Politecnica delle Marche, Ancona, Italy

\begin{abstract}
Organic farming is claimed to improve soil fertility. Nonetheless, among organic practices, net C-inputs may largely vary in amount and composition and produce different soil conditions for microbial activity and plant-root system adaptation and development. In this study, we hypothesised that, in the regime of organic agriculture, soil chemical and biochemical properties can substantially differ under contrasting crop rotation systems and produce conditions of soil fertility to which the plant responds through diverse growth and production. The impact of 13 years of alfalfa-crop rotation (P-C) and annual crop rotation (A-C) was evaluated on the build up of soil organic carbon (SOC), active (light fraction organic matter, LFOM; water soluble organic carbon, WSOC) and humic fraction [fulvic acids carbon (FAC), humic acids carbon (HAC)], soil biochemical properties [microbial biomass carbon $(\mathrm{MBC})$, basal respiration $(\mathrm{dBR})$, alkaline phosphatase (AmP), arylsulfatase (ArS), orto-diphenoloxidase $(o-$ $\mathrm{DPO})]$ and the amount of available macro-nutrients (N, P, and $\mathrm{S}$ ) at two different soil depths $(0-10 \mathrm{~cm}$ and $10-30 \mathrm{~cm})$ before and
\end{abstract}

Correspondence: Costantino Vischetti, Department of Agricultural, Food and Environmental Sciences, Università Politecnica delle Marche, via Brecce Bianche 10, 60131 Ancona, Italy.

$\mathrm{Tel}+39.071 .2204264-\mathrm{Fax}+39.071 .2204866$.

E-mail: c.vischetti@univpm.it

Key words: Organic farming; SOC; Enzymatic activities; Nutrients availability; Plant-root system.

Funding: the ConMarcheBio - Quality of Organic Cereals, financially supported this research. Rural Development Plan, Measure 1.2.4Action 2: Soil Fertility. The funding source had no involvement in any decision regarding the experimental design, data collection and discussion and preparation of the article for publication.

Received for publication: 9 September 2016.

Revision received: 9 June 2017.

Accepted for publication: 10 June 2017.

CC Copyright E. Monaci et al., 2017

Licensee PAGEPress, Italy

Italian Journal of Agronomy 2017; 12:831

doi:10.4081/ija.2017.831

This article is distributed under the terms of the Creative Commons Attribution Noncommercial License (by-nc 4.0) which permits any noncommercial use, distribution, and reproduction in any medium, provided the original author(s) and source are credited. after cultivation of wheat. We also studied the response of root morphology, physiology and yield of the plant-root system of wheat. Results showed that the level of soil fertility and plant-root system behaviour substantially differed under the two crop rotation systems investigated here. We observed high efficiency of the $\mathrm{P}-\mathrm{C}$ soil in the build up of soil organic carbon, as it was 2.9 times higher than that measured in the A-C soil. With the exception of $o$-DPO, P-C soil always showed a higher level of AmP and ArS activity and an initial lower amount of available $\mathrm{P}$ and $\mathrm{S}$. The P-C soil showed higher rootability and promoted thinner roots and higher root density. In the P-C soil conditions, the photosynthesis and yield of durum wheat were also favoured. Finally, cultivation of wheat caused an overall depletion of the accrued fertility of soil, mainly evident in the P-C soil, which maintained a residual higher level of all the chemical and biochemical properties tested.

\section{Introduction}

During the last 60 years agricultural activity has seriously depleted fertility of arable soils due to net oxidation and loss of soil organic carbon (SOC). Since SOC is considered the key factor to boost suitable soil conditions for crop production, EU policies focus on sustainable agricultural practices for the restoration of arable soils that currently have less than $2 \%$ of SOC (Romanyà and Rovira, 2011; Panagos et al., 2013).

In this regard, organic agriculture, relying on the distribution of organic amendments to sustain crop production, is inherently perceived and claimed as a viable practice to promote SOC and soil biological activity in arable soils (Marinari et al., 2006; Santos et al., 2012; Domínguez et al., 2013). Nonetheless, the actual benefits of organic farming to keep high level of SOC and to foster soil fertility have been lately questioned (Stockdale et al., 2002; Leifield, 2012; Parras-Alcantara et al., 2014).

Indeed, given the wide range of practices used within organic agriculture (distribution of organic amendments and/or cover crops and/or crop rotations with annual and/or perennial legumes), the net carbon inputs and carbon chemical composition are expected to largely vary along with microbial activity (Henriksen and Breland, 1999; Sainju et al., 2011). Although SOC quality and dynamics in soil are far from being comprehended (Joffre et al., 2001), SOC is conceptualised to comprise organic fractions categorised on the basis of their turn over rate (von Lützow et al., 2007). The active fraction is almost readily available for microbial breakdown and closely associated with nutrient supply. The humic fraction is more refractory to microbial degradation and considered to be the major reservoir of organic $\mathrm{C}$ in soil (von Lützow et al., 2007). Accordingly, farming practices used in a given organic system may favour a different balance among those organic pools 
and mediate for SOC accumulation and/or degradation. The presence of organic substances in soils influences the plant-root system in various ways. For instance, the increased amount of SOC improves soil structure (García-Orenes et al., 2012) and facilitates root elongation and proliferation (Lipiec et al., 2012). In addition to crop production, the level of available nutrients can influence post-embryonic root development and root architecture (LópezBucio et al., 2003). Finally, humic substances can directly induce the proliferation of lateral roots and root hairs or indirectly mediate for the up-take of nutrients (Canellas et al., 2012). The main aim of this study is to test the hypotheses that, in the regime of organic agriculture, a soil under different crop rotation systems can: i) substantially vary on the basis of SOC accumulation, soil metabolic activity and nutrient availability, and ii) differentiate soil conditions for the different adaptation and development of the plant-root system.

Therefore, in this research, we investigate the cumulative fertility of an organically managed soil after 13 years of two contrasting cropping systems, Alfalfa-Crop rotation (P-C) and Annual crop rotation $(\mathrm{A}-\mathrm{C})$ and the adaptation and development of the wheat plant-root system. The residual fertility left in soil after cultivation of wheat, is also investigated. To pursue the objective, we studied the level of: i) SOC and SOC-active and -humic fraction, ii) available amount of nitrogen, phosphorus and sulphur iii) soil biochemical activity, and iv) morphology, physiology and yield of the wheat plant-root system.

\section{Materials and methods}

\section{Experimental site}

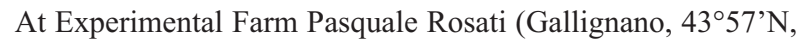
$13^{\circ} 43^{\prime} \mathrm{E}, 100 \mathrm{~m}$ a.s.1.) of the Marche Polytechnic University, a field experiment started in November 2011.

The climate here is temperate with average annual rainfall of $800 \mathrm{~mm}$ and a mean temperature of $15^{\circ} \mathrm{C}$. The highest mean temperature $\left(25.3^{\circ} \mathrm{C}\right)$ and the lowest mean precipitation $(34.2 \mathrm{~mm})$ usually occur in July whereas the lowest mean temperature $\left(5.8^{\circ} \mathrm{C}\right)$ and the highest precipitation $(94.3 \mathrm{~mm})$ usually occur in December (reference period 1981-2010, ASSAM, 2013). The period of experimentation, autumn-summer 2011-2012, was characterised by an exceptional precipitation events of $160 \mathrm{~mm}$, mainly snow, in February and 207 and $143 \mathrm{~mm}$ of rainfall in September and in November, respectively. Minimum temperature in February $\left(+3^{\circ} \mathrm{C}\right)$ was consistently lower than the mean value of the period, while a medium temperature of $2-3^{\circ} \mathrm{C}$ higher than the long period average was recorded in June, July and August (ASSAM, 2013). For this reason, the results, obtained from this single year of investigation, can be considered as preliminary observations that need to be validated during multiple growing seasons. Organic cropping system commenced in 1998 in a 2 ha area where two crop rotation systems, Alfalfa-Crop rotation (P-C) and Annual crop rotation (AC), were established and continued for 13 years (Table 1). The two

Table 1. Main key-management of the alfalfa-crop rotation and annual crop rotation systems (1998-2012).

\begin{tabular}{|c|c|c|c|c|c|c|}
\hline \multirow[b]{2}{*}{ Year } & \multicolumn{3}{|c|}{$\mathrm{P}-\mathrm{C}$} & \multicolumn{3}{|c|}{$\mathrm{A}-\mathrm{C}$} \\
\hline & Crop sequence & $\mathrm{e}^{*}$ Tillage $^{* *}$ & Organic amendment & Crop sequence* & Tillage** & Organic amendment \\
\hline 1998/1999 & Alfalfa & Summer ploughing & None & Sunflower & Summer ploughing & $\begin{array}{c}60 \mathrm{~kg} \mathrm{ha}^{-1} \text { of dry fleshings } \\
\left(3.5 \% \text { Norg; } 4 \% \mathrm{P}_{2} \mathrm{O}_{5}\right)\end{array}$ \\
\hline 1999/2000 & Alfalfa & None & None & Barley & Summer ploughing & None \\
\hline $2000 / 2001$ & Alfalfa & None & None & Sunflower & Summer ploughing & $\begin{array}{c}60 \mathrm{~kg} \mathrm{ha}^{-1} \text { of dry fleshings } \\
(3.5 \% \text { Norg })\end{array}$ \\
\hline $2001 / 2002$ & Alfalfa & None & None & Barley & Summer ploughing & $\begin{array}{c}25 \mathrm{~kg} \mathrm{ha}^{-1} \text { of triturated plumage } \\
\left(10 \% \text { Norg; } 4 \% \mathrm{P}_{2} \mathrm{O}_{5}\right)\end{array}$ \\
\hline $2002 / 2003$ & Alfalfa & None & None & Tick bean & Summer ploughing & $\begin{array}{l}440 \mathrm{~kg} \mathrm{ha}^{-1} \text { of guano } \\
\left(6 \% \text { Ntot; } 15 \% \mathrm{P}_{2} \mathrm{O}_{5}\right)\end{array}$ \\
\hline $2003 / 2004$ & Winter wheat & Summer ploughing & $\begin{array}{c}283 \mathrm{~kg} \mathrm{ha}^{-1} \text { of guano } \\
\left(6 \% \text { Ntot; } 15 \% \mathrm{P}_{2} \mathrm{O}_{5}\right) \\
300 \mathrm{~kg} \mathrm{ha}^{-1} \text { of stable manure } \\
(12.5 \% \text { Norg })\end{array}$ & Barley & Summer ploughing & None \\
\hline $2005 / 2006$ & Tick bean & Subsoiling & $\begin{array}{l}270 \mathrm{~kg} \mathrm{ha}^{-1} \text { chicken droppings } \\
\left(4 \% \text { Norg; } 4 \% \mathrm{P}_{2} \mathrm{O}_{5}\right)\end{array}$ & Barley & Subsoiling & None \\
\hline $2006 / 2007$ & Winter wheat & Subsoiling & $\begin{array}{c}283 \mathrm{~kg} \mathrm{ha}^{-1} \text { of guano } \\
\left(6 \% \mathrm{Ntot}^{\prime} 15 \% \mathrm{P}_{2} \mathrm{O}_{5}\right) \\
550 \mathrm{~kg} \mathrm{ha}^{-1} \text { of stable manure } \\
(12.5 \% \text { Norg })\end{array}$ & Tick bean & Subsoiling & $\begin{array}{l}440 \mathrm{~kg} \mathrm{ha}^{-1} \text { of guano } \\
\left(6 \% \text { Ntot; } 15 \% \mathrm{P}_{2} \mathrm{O}_{5}\right)\end{array}$ \\
\hline $2007 / 2008$ & Alfalfa & Shallow tillage & None & Barley & Shallow tillage & None \\
\hline $2008 / 2009$ & Alfalfa & None & None & Tick bean & Shallow tillage & $\begin{array}{l}440 \mathrm{~kg} \mathrm{ha}^{-1} \text { of guano } \\
\left(6 \% \text { Ntot; } 15 \% \mathrm{P}_{2} \mathrm{O}_{5}\right)\end{array}$ \\
\hline $2009 / 2010$ & Alfalfa & None & None & Barley & Shallow tillage & None \\
\hline $2010 / 2011$ & Alfalfa & None & None & $\begin{array}{c}\text { Bare fallow } \\
\text { (spontaneous vegetati }\end{array}$ & None & None \\
\hline 2011/2012 & Winter wheat & Subsoiling & $\begin{array}{l}1600 \mathrm{~kg} \mathrm{ha}^{-1} \text { of pot } \\
\text { ale and chicken droppings } \\
\left(5 \% \text { Norg, } 5 \% \mathrm{P}_{2} \mathrm{O}_{5}\right)\end{array}$ & Winter wheat & Subsoiling & $\begin{array}{l}1600 \mathrm{~kg} \mathrm{ha}^{-1} \text { of pot ale and } \\
\text { chicken droppings } \\
\left(5 \% \text { Norg, } 5 \% \mathrm{P}_{2} \mathrm{O}_{5}\right)\end{array}$ \\
\hline
\end{tabular}

P-C, alfalfa-crop rotation; A-C, annual crop rotation; alfalfa, Medicago sativa; winter wheat, Triticum durum Desf var. Claudio; barley, Hordeum vulgare var Herdas; tick bean, Vicia faba minor var Vesuvio and/or var. Chiaro di Torrelama; sunflower, Helianthus annuus; summer ploughing, $40 \mathrm{~cm}$; subsoiling, $25 \mathrm{~cm}$; shallow tillage, $20 \mathrm{~cm}$. 
parcels, P-C and A-C, were adjacent to each other, on a similar landscape and individuated in a surface of $5200 \mathrm{~m}^{2}$. Within each parcel, three homogeneous pseudo-replicates blocks were identified on the basis of the exposition and slope and divided in 4 subplots each. The subplot samples had been considered nested within blocks. In order to exclude sampling in marginal borders, the actual sampled area was equivalent to $1440 \mathrm{~m}^{2}$ in both P-C and A-C parcels.

In the P-C parcel, a crop rotation mainly based on the perennial legume alfalfa (Medicago sativa L.) and on wheat (Triticum durum var Claudio), with the exception in 2005 of tick-bean (Vicia faba minor var Chiaro di Torrelana), was established. In this parcel, the summer ploughing $(0-40 \mathrm{~cm})$ was done in 1998, in order to suppress weeds and to allow a properly settled sowing-bed for the alfalfa crop. The soil was ploughed again in 2003 before the cultivation of wheat in order to suppress weeds and to facilitate air and water infiltration. Thereafter, the soil was mostly shallowly tilled. In the P-C parcel, the distribution of organic amendments occurred for 4 years out of 13 years of cultivation.

In the A-C parcel, a cropping system based on annual grain crops, sunflower (Helianthus annuus), tick-bean (Vicia faba minor var Vesuvio), barley (Hordeum vulgare var Herdas) and winter wheat (Triticum durum var. Claudio) with the exception of bare fallow in 2010, was established. From 1998 to 2003, the soil was ploughed at $0-40 \mathrm{~cm}$ in order to suppress weeds before the cultivation of grain crops, and it was sub-soiled $(0-25 \mathrm{~cm})$ or shallowly tilled in the following years. In the A-C parcel, with the exception of barley, the crop production was sustained by the distribution of organic amendments.

In the P-C parcel, flame weeding was used to suppress Cuscuta spp. when needed, whereas weeds (mainly Papaver rhoeas, Sinapis arvensis L., Chenopodium album, Rumex obtusifolius L.) were controlled either by harrowing at the very early stage of the grain crops growth (e.g., post emergence of wheat) or by inter-row hoeing (e.g., post emergence of tick bean). None weeding was needed or done for barley crop.

Alfalfa biomass production ranged from $5.5 \mathrm{tha}^{-1}\left(1^{\text {st }}\right.$ year of harvest) to $9 \mathrm{t} \mathrm{ha}^{-1}$ ( $5^{\text {th }}$ year of harvest) with a maximum yield of $13.5 \mathrm{t} \mathrm{ha}^{-1}\left(2^{\text {nd }}\right.$ and $3^{\text {rd }}$ year of harvest $)$. Alfalfa biomass was cut for hay two or three times per year. Grain production of wheat ranged from 3 to $5 \mathrm{t} \mathrm{ha}^{-1}$, mean production of barley varied between 2 and $3 \mathrm{t} \mathrm{ha}^{-1}$ and tick bean produced about $1.8-2 \mathrm{t} \mathrm{ha}^{-1}$ of grain. In the A-C parcel, crop residues were mostly removed and the remnants were left on soil and/or incorporated with soil tillage. A summary of crop sequences and the main keys of agricultural practices are outlined in Table 1.

The fourteenth year of $\mathrm{P}-\mathrm{C}$ and A-C rotations was aligned. Soil was sub-soiled, and winter wheat (Triticum durum var Claudio) was sown on November $17^{\text {th }}, 2011$ (280 kg of seed ha-1) and harvested on July $6^{\text {th }}, 2012$. On January $27^{\text {th }}$ a finger harrow was used twice to suppress weeds.

\section{Soil sampling and chemical and biochemical analysis}

Soil was sampled in November 2011, 13 years after the establishment of P-C and A-C, in order to assess soil cumulative fertility, and it was sampled again in July 2012, after wheat harvest, in order to evaluate soil residual fertility.

Soil samples were collected after the sub-soiling. A non-systematic (W) pattern (Paetz and Wilke, 2005) was used to collect a number of 24 composite soil samples ( $\cong 1 \mathrm{~kg}$ each) at $0-10 \mathrm{~cm}(12$ samples) and 10-30 cm (12 samples) of depth from P-C and/or A$\mathrm{C}$ parcel. Each composite sample comes from three subsamples of soil of each subplot.
Collected soil was air-dry, passed through a $2 \mathrm{~mm}$ sieve and stored at $+4^{\circ} \mathrm{C}$ prior to chemical and biochemical analyses.

Soil texture was determined by particle dispersion and sedimentation and defined according to USDA classification. Bulk density was measured by the core method (Wilke, 2005), sampling three undisturbed soil samples $(0-30 \mathrm{~cm})$ from each parcel by means of a thin-walled metal cylinder with a volume of $500 \mathrm{~cm}^{3}$. Soil $\mathrm{pH}$ was measured at 1:2.5 (w/v) soil/water ratio.

A subsample of soil was sieved at $0.5 \mathrm{~mm}$ to measure soil organic carbon and organic carbon fractions. One $\mathrm{g}$ of soil was used to determine soil organic carbon (SOC). $5 \mathrm{~g}$ of soil were used to sequentially extract organic carbon fractions. Firstly, soil was transferred into a $50 \mathrm{~mL}$ centrifuge tube and repeatedly treated with $25 \mathrm{~mL}$ of deionised water. Soil was allowed to sediment to physically remove free organic residues (the coarse light fraction organic matter, LFOM $<1.0 \mathrm{~g} \mathrm{~cm}^{-3}$ ) (Cookson et al., 2008). After LFOM removal, the soil sample was centrifuged and the supernatant was collected to determine water-soluble organic carbon (WSOC). The soil was then extracted with $50 \mathrm{~mL}$ of a $0.1 \mathrm{M}$ $\mathrm{Na}_{4} \mathrm{P}_{2} \mathrm{O}_{7}+\mathrm{NaOH}$ solution $(1: 10 \mathrm{w}: \mathrm{v})$ in order to determine the humic organic carbon fraction. The total extractable carbon solution (TEC) was acidified $(\mathrm{pH} \cong 2)$ to separate humic and fulvic acids (HAs and FAs). Fulvic acids were then purified in polyvinylpolypyrrolidone $\sim 110 \mu \mathrm{m}$ particle size (Fluka Analytical). The amount of soil organic carbon (SOC), water soluble organic carbon (WSOC), humic acids carbon (HAC) and fulvic acids carbon (FAC) was determined after oxidation with dichromate $\left(\mathrm{K}_{2} \mathrm{Cr}_{2} \mathrm{O}_{7} 0.0667 \mathrm{M}\right.$ and/or $\left.0.167 \mathrm{M}\right)$ and by back-titration with ferrous salt (Mohr's salt $\left(\mathrm{NH}_{4}\right)_{2} \mathrm{Fe}\left(\mathrm{SO}_{4}\right)_{2} * 6 \mathrm{H}_{2} \mathrm{O} 0.0333 \mathrm{M}$ and/or $0.5 \mathrm{M})$

SOC and SOC fractions were measured on 24 composite soil samples from P-C (12 samples at 0-10 cm and 12 samples at $10-30$ $\mathrm{cm})$ and 24 composite soil samples from A-C (12 samples at 0-10 $\mathrm{cm}$ and 12 samples at $10-30 \mathrm{~cm}$ ).

Available $\mathrm{N}-\mathrm{NO}_{3}$ and $\mathrm{S}-\mathrm{SO}_{4}$ were determined by extracting 10 $\mathrm{g}$ of soil $(2 \mathrm{~mm}$ sieved) with a $0.01 \mathrm{M}$ of $\mathrm{KCl}$ solution and quantified by the ion chromatography system (Dionex ICS1000) equipped with IonPac AG9-HC (4x50 mm) guard and IonPac AS9$\mathrm{HC}$ analytical $(4 \times 250 \mathrm{~mm})$ column. A total number of 24 composite soil samples from P-C (12 samples at $0-10 \mathrm{~cm}$ and 12 samples at $10-30 \mathrm{~cm})$ and 24 composite soil samples from A-C (12 samples at $0-10 \mathrm{~cm}$ and 12 samples at $10-30 \mathrm{~cm})$ were extracted and analysed for $\mathrm{N}-\mathrm{NO}_{3}$ and $\mathrm{S}-\mathrm{SO}_{4}$ content.

Since by using the $0.01 \mathrm{M}$ of $\mathrm{KCl}$ extracting solution it was not possible to determine $\mathrm{P}-\mathrm{PO}_{4}$, available $\mathrm{P}$ was measured as Olsen-P. Briefly, $2.5 \mathrm{~g}$ of soil ( $2 \mathrm{~mm}$ sieved) were added with $50 \mathrm{~mL}$ of $0.5 \mathrm{M}$ of $\mathrm{NaHCO}_{3}(\mathrm{pH}=8.5)$ extracting solution, shaken for $30 \mathrm{~min}$ and filtered throughout charcoal. The filtrate $(10 \mathrm{~mL})$ was added with $1 \mathrm{~mL}$ of $\mathrm{H}_{2} \mathrm{SO}_{4}$ and $30 \mathrm{~mL}$ of the ammonium molybdate-antimony potassium tartrate-ascorbic acid (Murphy-Riley) colour developing solution. Absorbance of the blue solution was read at $700 \mathrm{~nm}$ in a Cary 50 Scan (Varian) UV-vis spectrophotometer. A total number of 12 composite soil samples from P-C (6 samples at $0-10 \mathrm{~cm}$ and 6 samples at $10-30 \mathrm{~cm}$ ) and 12 composite soil samples from A-C (6 samples at $0-10 \mathrm{~cm}$ and 6 samples at $10-30 \mathrm{~cm})$ were analysed for the P-Olsen content.

All the microbial and biochemical properties were measured on soil sieved a $2 \mathrm{~mm}$ and adjusted at $40 \%$ of the soil water holding capacity.

Microbial basal respiration (daily rate, $\mathrm{dBR}$ ) was determined by trapping $\mathrm{CO}_{2}$ (from $30 \mathrm{~g}$ of soil, $2 \mathrm{~mm}$ sieved, adjusted at the moisture content of $40 \%$ of water holding capacity) in $10 \mathrm{~mL}$ of $0.5 \mathrm{M} \mathrm{NaOH}$ solution within sealed incubation vessels over a $21-$ 
day period. $\mathrm{CO}_{2}$ concentration was determined by adding $\mathrm{BaCl}_{2}$ $(20 \% \mathrm{w} / \mathrm{v}$ aqueous solution) and subsequent titration with $0.1 \mathrm{M}$ $\mathrm{HCl}$ solution (Dumontet and Mathur, 1989).

Microbial biomass-C content (MBC) was determined by the fumigation and extraction method (Vance et al., 1987). Briefly, 10 $\mathrm{g}$ of soil (2 mm sieved) either non-fumigated or fumigated in $\mathrm{CHCl}_{3}$ were extracted with $25 \mathrm{~mL}$ of the saline solution $\mathrm{K}_{2} \mathrm{SO}_{4}$ $0.5 \mathrm{M}$ and determined for microbial $\mathrm{C}$ after oxidation with dichromate $\left(\mathrm{K}_{2} \mathrm{Cr}_{2} \mathrm{O}_{7} \quad 0.0667 \mathrm{M}\right)$ and by back-titration with $\left(\mathrm{NH}_{4}\right)_{2} \mathrm{Fe}\left(\mathrm{SO}_{4}\right)_{2} * 6 \mathrm{H}_{2} \mathrm{O} 0.0333 \mathrm{M}$.

Alkaline phosphatase (AmP) and arylsulfatase (ArS) activities were assayed according to the method of Eivazi and Tabatabai (1977) and Tabatabai and Bremner (1970), respectively. Briefly, 1 $\mathrm{g}$ of soil (2 mm sieved) was added with $4 \mathrm{~mL}$ of modified universal buffer (MUB) $\mathrm{pH}=11$ and $1 \mathrm{ml}$ of $p$-nitrophenyl phosphate $(0.05$ $\mathrm{M})$ to determine $\mathrm{AmP}$, or $4 \mathrm{~mL}$ of acetate buffer $\mathrm{pH}=5.8$ and $1 \mathrm{ml}$ of $p$-nitrophenyl sulfate $(0.05 \mathrm{M})$ to determine $\mathrm{ArS}$, and incubated at $37^{\circ} \mathrm{C}$ for $1 \mathrm{~h}$. Adding $1 \mathrm{~mL}$ of $\mathrm{CaCl}_{2}(0.5 \mathrm{M})$ and $4 \mathrm{~mL}$ of $\mathrm{NaOH}$ $(0.5 \mathrm{M})$ stopped the assays. Absorbance of $p$-nitrophenol $(p \mathrm{NP})$ released was read at $420 \mathrm{~nm}$ in a Cary 50 Scan (Varian) UV-vis spectrophotometer. Orto-diphenoloxidase (o-DPO) was assayed according to the method of Perucci et al. (2000). Briefly, $1 \mathrm{~g}$ of soil was added with $2 \mathrm{~mL}$ oxygenated $0.1 \mathrm{M}$ phosphate buffer $\mathrm{pH}=6.5$ and $3 \mathrm{~mL}$ of $0.2 \mathrm{M}$ cathecol:proline (1:1 ratio) and incubated at $30^{\circ} \mathrm{C}$ for $10 \mathrm{~min}$. Absorbance of the 4 -(N-proline)-o-benzoquinone (red compound) formed was read at $525 \mathrm{~nm}$ in a Cary 50 Scan (Varian) UV-vis spectrophotometer.

A total number of 12 composite soil samples from P-C (6 samples at $0-10 \mathrm{~cm}$ and 6 samples at $10-30 \mathrm{~cm})$ and 12 composite soil samples from A-C (6 samples at 0-10 $\mathrm{cm}$ and 6 samples at 10-30 $\mathrm{cm})$ were assayed for each investigated biochemical property.

In order to better figure out the balance of SOC fractions and to highlight microbial activity dynamics, the relative abundance of water soluble organic carbon and humic carbon was calculated as the percentage ratio WSOC*100/SOC and (FAC+HAC)*100/SOC and the relative abundance of $\mathrm{MBC}$ content and $\mathrm{dBR}$ activity was calculated as the percentage ratio $\mathrm{MBC}^{*} 100 / \mathrm{SOC}$ and dBR*100/SOC.

\section{Crop measurements}

Root length and topography were described throughout the installation of rhizotrons (Dauer et al., 2009). In order to minimise the disturbance of the rooting environment and to avoid the overproduction of roots associated with tip damage (Vogt et al., 1998), the rhizotrons were installed in P-C and A-C parcels immediately after sowing wheat, three months before the beginning of the images collection. The windows where installed at $5-7 \mathrm{~cm}$ from the sown row by digging the holes partially mechanically and partially by hand in order to remove the soil closer to the row with a minimal disturbance of the profile and to avoid compaction. When needed, a small amount of soil derived from the same hole was added between the acetate window and the soil profile in order to fill any discontinuity. In order to cope with the issue of possible insufficient spatial sampling (Bengough et al., 2000), a large number of boxes (24) were uniformly distributed over the experimental surface. The rhizotrons had the dimension of $50 \mathrm{~cm}$ of width $\mathrm{x} 50$ $\mathrm{cm}$ of depth in which over $80 \%$ of the total wheat root system is included (Jackson et al., 1996).

From February $27^{\text {th }}$ (terminal spikelet), after the first seminalroots appeared at the rhizotron window, the observation of elongation of the either seminal and nodal (Morita and Abe, 1996) root axis, from both main stems and tillers, was scheduled bi-weekly until May $5^{\text {th }}$. Images of the rhizotrons were taken using a digital camera (Canon EOS 1100 D, Tokyo, Japan) with a 12 Megapixel resolution. The pictures collected were cut exactly at the rhizotron windows size and corrected for possible curvature by the RDF software (IUAV, Venezia, Italy). The images were analysed to assess the number of tips, the single root main axis elongation rate and the topographic distribution of primary roots by dividing the rhizotron windows on 5 layers of $10 \mathrm{~cm}$ in depth excluding any lateral roots from measurements. Only the fully visible roots were considered to determine single root elongation while roots partially grown outside the rhizotron screen were excluded.

On April $20^{\text {th }}$ (spike growth), the diameter of primary roots, collected from 96 wheat seedlings per treatment, being 8 plants per subplot, was measured. Considering the small size of the root at that time, a wide soil sample was collected largely overcoming the soil volume explored by the roots in order to minimise fragment losses. Roots were carefully washed free of soil and individually laid on a scanner (Hp Scanjet G4050). All collected root images were processed and analysed through the DigiRootTM software (Digital Processing Solutions, USA) for diameter determination.

Root weight density was measured on April $24^{\text {th }}$. A total of 24 soil cores of known volume $(5 \mathrm{~cm}$ diameter $\times 30 \mathrm{~cm}$ depth), one per subplot, were collected from between crop rows at $10 \mathrm{~cm}$ from the sowing line, by using a manual auger. The soil cores collected were then divided into two subsamples to determine root density at 0-10 $\mathrm{cm}$ and 10-30 $\mathrm{cm}$ of soil depth, separately.

Soil samples were soaked in water for 30 minutes and roots were gently washed under running water using a $0.21 \mathrm{~mm}$ sieve to collect the largest amount of root fragments that were then picked up by using tweezers. The cleaned roots were dried at $75^{\circ} \mathrm{C}$ to constant weight and weighed. Root density was then calculated as the ratio root weight: soil volume.

Root respiration was measured on May $15^{\text {th }}$ (anthesis) and considered as an index of root metabolic activity. 36 root samples were collected using a manual auger from each parcel (3 per subplot) at a depth of $10 \mathrm{~cm}$. The root tip was excluded from the measurements, and the portions of root were selected from 0.5 to $2 \mathrm{~cm}$ from the tip. Only portions of white and healthy primary roots were collected, rinsed and immediately immersed in a 2-(N-morpholino) ethanesulfonic acid buffer solution (MES), allowed to stabilise at $22^{\circ} \mathrm{C}$ for approximately 20 minutes and inserted in the Oxygraph chamber at constant temperature $\left(22^{\circ} \mathrm{C}\right)$ equipped with Clark-type oxygen electrode (Hansatech Oxygraph, King's Lynn, UK) in order to measure $\mathrm{O}_{2}$ consumption until a steady slope displaying the $\mathrm{O}_{2}$ consumption rate could be reached ( $\sim 15$ minutes). The roots were then dried for $48 \mathrm{~h}$ at $70^{\circ} \mathrm{C}$ and weighed to determine specific respiration rate.

Plant photosynthetic gas exchange and chlorophyll content were determined on recent, fully expanded selected leaves on May $17^{\text {th }}$ (Khan et al., 2007). Net photosynthesis (Pn) was determined on the leaves using an LC Pro (ADC BioScientific Ltd., Hoddesdon, UK) portable infrared gas analyser (IRGA). The IRGA was equipped with a leaf-clamped cuvette covering. 5.80 $\mathrm{cm}^{2}$ of the leaf area and measurements were taken under field conditions (i.e., inlet relative humidity was around $25 \%$, light intensity was about $1100 \mu \mathrm{mol} \mathrm{m} \mathrm{m}^{-2} \mathrm{~s}^{-1}$ and chamber temperature ranged from 15.3 to $27.2^{\circ} \mathrm{C}$ ). The measurements were carried out between10:00 a.m. and 3:00 p.m. (solar time).

Relative chlorophyll concentrations were estimated using a SPAD-502 chlorophyll meter (Minolta, Tokyo, Japan) and expressed as SPAD index (Markwell et al., 1995). Each chlorophyll measurement was derived from the readings taken repeatedly at the three apices of a triangle drawn on the leaf lamina. In this case, a total number of 24 measurements, one per subplot, were 
carried out. In July, the wheat crop was harvested, and the total yield was determined. Firstly, the wheat crop was partially harvested in an area of $5 \mathrm{~m}^{2}(2 \times 12$ subplots $)$ in each P-C and A-C parcel using a mower (cutter bar of $100 \mathrm{~cm}$ of length). A total number of 600 wheat plants $(50 \times 12$ subplots) for both P-C and A-C were brought into laboratory in order to manually count the number of ears per $\mathrm{m}^{2}$ and fertile spikelets per ear. The number of caryopses per ear was determined after threshing with a Wintersteiger LD 180 thresher. Protein content was determined through an Infratec 1241 analysis at the C.E.R.M.I.S [Research and Experimental Centre for Crop Improvement, Tolentino (MC), Italy].

\section{Statistical analysis}

The analysis' results of the 4 subplots were averaged at block level. After that soil chemical and biochemical properties and root density were analysed by the two-way ANOVA analysis. The factors considered for the statistical analysis were crop rotation, depth and crop rotation $\mathrm{x}$ depth. The Tukey's HSD test $(\alpha=0.05)$ was used for mean separation whenever the ANOVA indicated a significant difference due to the above factors. When crop rotation $\times$ depth interaction was significant the mean values of each possible combination of depth and treatment were compared. Root diameter and all data referring to plant metabolism and crop production were analysed by the Student's t test $(\alpha=0.05)$ for mean separation.

\section{Results}

Soil texture yielded similar particle size distribution that indicates the presence of a clay loam in both P-C and A-C parcels. Soil bulk density was not statistically different being $1.40( \pm 0.42) \mathrm{g} \mathrm{cm}^{-3}$ in the P-C and $1.48( \pm 0.55) \mathrm{g} \mathrm{cm}^{-3}$ in the A-C soil, as well as the soil $\mathrm{pH}\left(\mathrm{H}_{2} \mathrm{O}\right)$ that was $8.00( \pm 0.12)$ and $8.15( \pm 0.01)$ in $\mathrm{P}-\mathrm{C}$ and A-C soils, respectively. On the other hand, the presence of the two contrasting crop rotation systems induced a different amount of $\mathrm{N}_{\text {tot }}$ that, in the P-C soil, was $2.30( \pm 0.03) \mathrm{g} \mathrm{kg}^{-1}$ at $0-10 \mathrm{~cm}$ and
A

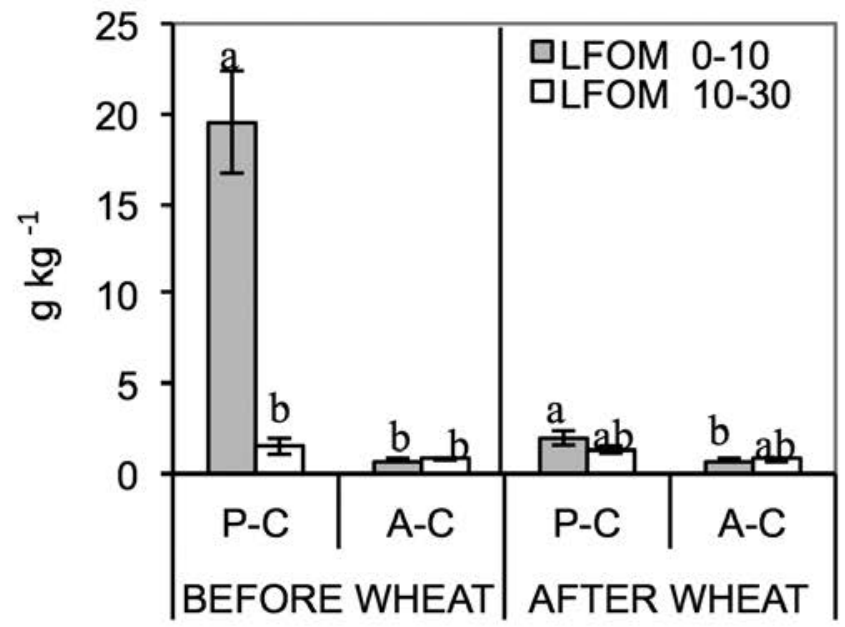

B

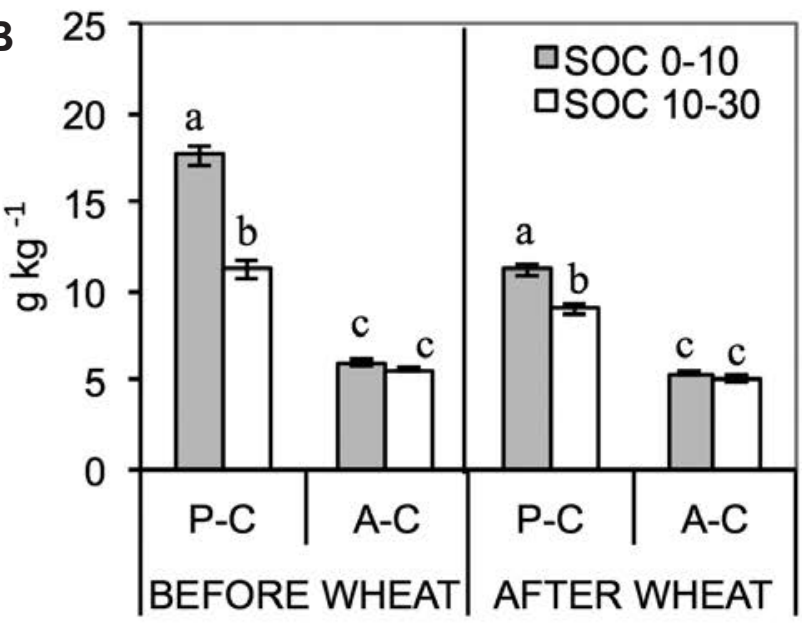

C

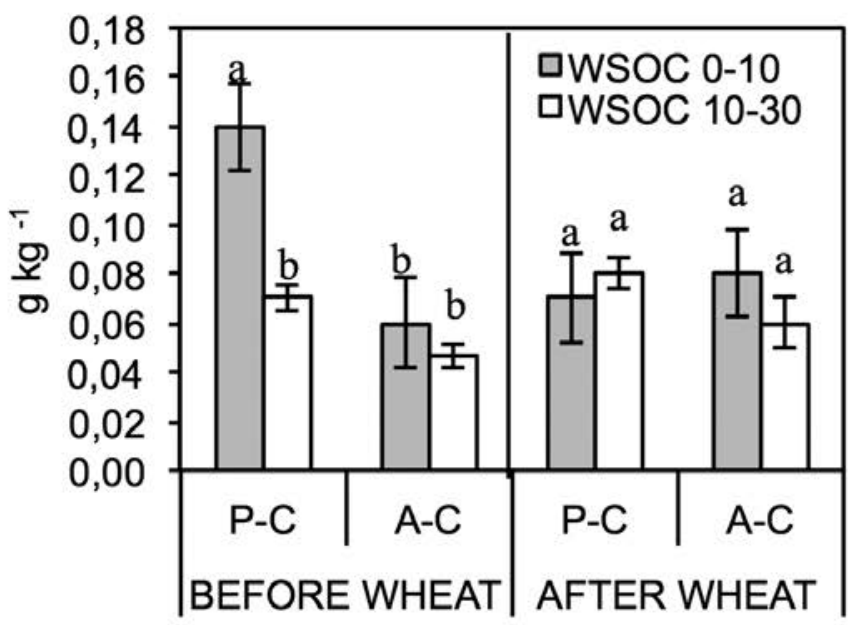

D

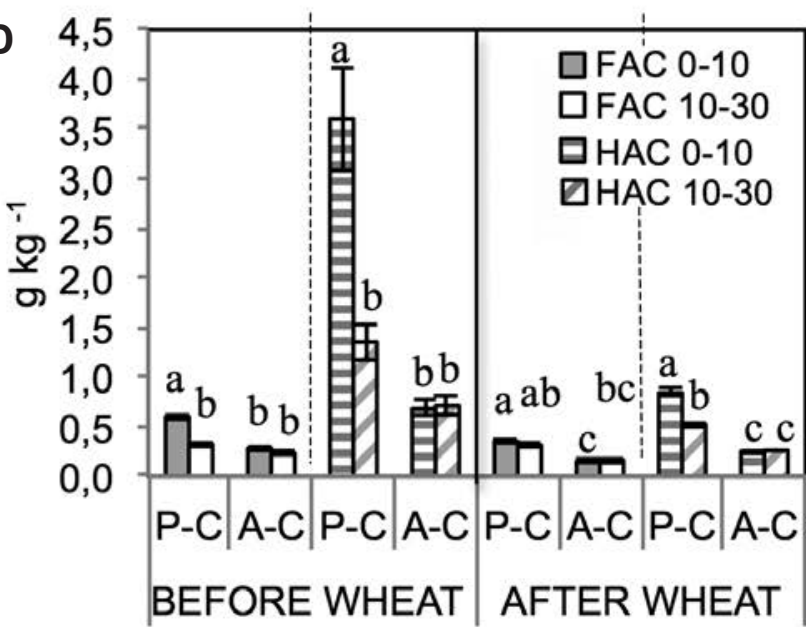

Figure 1. A) Light fraction organic matter (LFOM); B) soil organic carbon (SOC); C) water soluble organic carbon (WSOC); D) fulvic acids carbon (FAC) and humic acids carbon (HAC) in the alfalfa-crop rotation (P-C) and annual crop rotation (A-C) soils, at 0-10 and $10-30 \mathrm{~cm}$, before and after cultivation of wheat. Different letters denote significant differences (Tukey's honest significant difference test $P<0.05)$ of the mean values ( \pm standard deviation) between $P-C$ and $A-C$ soils due to crop rotation $\times$ depth interaction, within each sampling period (statistical analysis of data collected before wheat is separated from that of data collected after wheat). 
$1.73( \pm 0.01)$ at $10-30 \mathrm{~cm}$ and in the A-C soil was $1.14 \mathrm{~g} \mathrm{~kg}^{-1}$ $( \pm 0.02)$ being not significantly different between depths. The two cropping systems also differentiated soil conditions for total amount of SOC and SOC-fractions and rate of soil biochemical properties and nutrients availability.

\section{Soil organic carbon and soil organic carbon-fractions before and after cultivation of wheat}

The cumulative amount of soil organic carbon (SOC) and the active (LFOM and WSOC) and humic (FAC and HAC) fractions, at two depths and before and after the cultivation of wheat, are reported in Figure 1.

Before the cultivation of wheat, a higher accumulation of all organic pools was evidenced in the P-C compared to the A-C soil at $0-10 \mathrm{~cm}$ depth, while no significant differences were found for the $10-30 \mathrm{~cm}$ depth with the exception of SOC fraction, which resulted higher in the P-C soil compared to the A-C soil.

The high amount of LFOM of $19.50( \pm 2.80) \mathrm{g} \mathrm{kg}^{-1}$ in the P-C soil was markedly in contrast with the very low content of 0.73 $( \pm 0.07) \mathrm{g} \mathrm{kg}^{-1}$ measured in the A-C soil (Figure 1A). In the P-C soil, the SOC turned out to be $3(0-10 \mathrm{~cm})$ to 2-times $(10-30 \mathrm{~cm})$ higher than that in the A-C soil (Figure 1B)

Compared to $\mathrm{A}-\mathrm{C}$, the $\mathrm{P}-\mathrm{C}$ soil contained higher amount of WSOC at $0-10 \mathrm{~cm}$ (Figure 1C) and higher humic-C fraction (FAC and HAC) (Figure 1D) at $0-10 \mathrm{~cm}$ depth while no significant differences were found at 10-30 cm depth for both fractions.

After the cultivation of wheat, most of the organic $\mathrm{C}$ pools depleted in both A-C and P-C soils, though at different levels (Figure 1).

Despite the remaining wheat stubble, LFOM dropped to 1.98 $( \pm 0.40) \mathrm{g} \mathrm{kg}^{-1}$ diminishing by about $90 \%$ of the initial content in the P-C soil $(0-10 \mathrm{~cm})$. Conversely, the amount of LFOM remained almost unvaried in the A-C soil (Figure 1A).

A relative loss of $36 \%$ (from 17.60 to $11.20 \mathrm{~g} \mathrm{~kg}^{-1}$ ) and $20 \%$ (from 11.20 to $9.00 \mathrm{~g} \mathrm{~kg}^{-1}$ ) of the initial amount of SOC was observed respectively at $0-10 \mathrm{~cm}$ and $10-30 \mathrm{~cm}$ in the $\mathrm{P}-\mathrm{C}$ soil, while SOC diminished by a mean value of $10 \%$ in the $\mathrm{A}-\mathrm{C}$ soil (Figure 1B).

In the P-C soil, WSOC diminished by $50 \%$ and reached a level not statistically different from the A-C soil where the amount of soluble carbon remained almost unvaried (Figure 1C).

A noticeable detrimental effect was observed on the humic fraction. FAC declined by a mean value of $44 \%$ in both P-C and A-
C soils. In the P-C soil, HAC depleted by $77 \%$ and $61 \%$ at $0-10$ and $10-30 \mathrm{~cm}$, respectively, whilst in the A-C soil, HAC decreased by a mean value (with no difference between depths) of $63 \%$ (Figure 1D).

To better figure out the general balance of SOC fractions, the relative abundance of $\mathrm{WSOC}$ and $\mathrm{HAC}+\mathrm{FAC}$ in relation to $\mathrm{SOC}$ was calculated before and after the cultivation of wheat (Table 2). Indeed, higher percentage of humic fraction, with respect to SOC, was evidenced in the P-C soil before cultivation of wheat $(25.74 \pm 2.3 \%$ in the $0-10 \mathrm{~cm}$ layer and $15.70 \pm 3.3$ in the $0-30 \mathrm{~cm}$ layer), which significantly depleted in the first $10 \mathrm{~cm}$ layer after the cultivation of wheat $(9.90 \pm 1.52 \%)$. A relative high percentage of the humic fraction was found also in the A-C soil, which remained almost at the same level after the cultivation of wheat. WSOC fraction percentage was found to be the same in the P-C and $\mathrm{A}-\mathrm{C}$ soils before the cultivation of wheat showing a decrease in the $\mathrm{P}-\mathrm{C}$ soil and an increase in the A-C soil after the cultivation of wheat.

\section{Soil biochemical properties and the available nitrogen, phos- phorus and sulphur before and after cultivation of wheat}

The investigated biochemical properties were constantly higher in the $\mathrm{P}-\mathrm{C}$ than in the A-C soil, the only exception being $o$-DPO activity, which on average was $23 \%$ higher in the A-C soil (Table 3 ). The $\mathrm{MBC}$ content was from 44 to $30 \%$ (average between depths) higher in the P-C than in the A-C soil before and after the cultivation of wheat, respectively. Due to the major microbial content, $\mathrm{dBR}$ rate was also higher in the $\mathrm{P}-\mathrm{C}$ than in the $\mathrm{A}-\mathrm{C}$ soil before and after the cultivation of wheat, respectively (Table 3 ).

Results of $\mathrm{MBC}$ and $\mathrm{dBR}$ relative abundance in relation to SOC, are reported in Table 2. The relative abundance of $\mathrm{MBC}$ did not differed between the P-C and A-C soils at $0-10 \mathrm{~cm}$ while it was lower in the $\mathrm{P}-\mathrm{C}$ than in the A-C soil at $10-30 \mathrm{~cm}$ of depth. In contrast, $\mathrm{dBR}$ showed the tendency to be always relatively higher in the A-C than in the P-C soil (Table 2).

The availability of nutrients differed in the soils of the two cropping systems. As expected, under an N-fixing crop such as alfalfa, the P-C soil had the greatest amount of readily available N$\mathrm{NO}_{3}$ (Table 3). In contrast, before wheat cultivation, the amount of available $\mathrm{P}-\mathrm{PO}_{4}$ and $\mathrm{S}-\mathrm{SO}_{4}$ was found to be higher in the A-C than in the $\mathrm{P}-\mathrm{C}$ soil. Nonetheless, the residual amount of these macronutrients decreased more in the A-C than in the $\mathrm{P}-\mathrm{C}$ soil. This was particularly true for sulfates, which were not even detect-

Table 2. Relative abundance expressed as the percentage amount of water-soluble organic carbon, fulvic+humic acids carbon, microbial biomass carbon, and basal respiration in relation to the total amount of soil organic carbon in the alfalfa- and annual crop rotation soils, at different depths, before and after cultivation of wheat.

\begin{tabular}{llcccc} 
& & \multicolumn{2}{c}{ Before wheat } & & After wheat \\
& Sampling depth $(\mathrm{cm})$ & P-C & A-C & & A-C \\
WSOC & $0-10$ & $0.82( \pm 0.2)^{\mathrm{a}}$ & $0.98( \pm 0.0)^{\mathrm{a}}$ & $0.51( \pm 0.1)^{\mathrm{b}}$ & $1.36( \pm 0.4)^{\mathrm{a}}$ \\
$\%$ & $10-30$ & $0.69( \pm 0.1)^{\mathrm{a}}$ & $0.80( \pm 0.3)^{\mathrm{a}}$ & $0.93( \pm 0.2)^{\mathrm{ab}}$ & $1.43( \pm 0.3)^{\mathrm{a}}$ \\
FAC+HAC & $0-10$ & $25.74( \pm 2.3)^{\mathrm{a}}$ & $10.21( \pm 2.3)^{\mathrm{b}}$ & $9.90( \pm 1.2)^{\mathrm{a}}$ & $7.78( \pm 02)^{\mathrm{b}}$ \\
$\%$ & $10-30$ & $15.70( \pm 3.3)^{\mathrm{b}}$ & $15.52( \pm 2.0)^{\mathrm{b}}$ & $7.85( \pm 0.7)^{\mathrm{b}}$ & $7.93( \pm 0.8)^{\mathrm{b}}$ \\
\hline MBC & $0-10$ & $2.07( \pm 0.2)^{\mathrm{a}}$ & $1.96( \pm 0.1)^{\mathrm{a}}$ & $2.03( \pm 0.2)^{\mathrm{a}}$ & $1.85( \pm 0.2)^{\mathrm{a}}$ \\
$\%$ & $10-30$ & $1.50( \pm 0.2)^{\mathrm{b}}$ & $1.84( \pm 0.1)^{\mathrm{ab}}$ & $1.45( \pm 0.1)^{\mathrm{b}}$ & $1.91( \pm 0.2)^{\mathrm{a}}$ \\
dBR & $0-10$ & $0.74( \pm 0.1)^{\mathrm{b}}$ & $1.03( \pm 0.1)^{\mathrm{a}}$ & $0.86( \pm 0.1)^{\mathrm{b}}$ & $1.27( \pm 0.0)^{\mathrm{a}}$ \\
$\%$ & $10-30$ & $0.77( \pm 0.1)^{\mathrm{b}}$ & $1.07( \pm 0.0)^{\mathrm{a}}$ & $0.82( \pm 0.1)^{\mathrm{b}}$ & $1.23( \pm 0.1)^{\mathrm{a}}$ \\
\hline
\end{tabular}

P-C, alfalfa-crop rotation; A-C, annual crop rotation; WSOC, water soluble organic carbon; FAC, fulvic acids carbon; HAC, humic acids carbon; MBC, microbial biomass carbon; dBR, basal respiration. a,bDifferent letters denote significant differences (Tukey's HSD test $\mathrm{P}<0.05$ ) of the mean values ( \pm standard deviation) between $\mathrm{P}-\mathrm{C}$ and A-C soils due to crop rotation $\mathrm{x}$ depth interaction, within each sampling period (statistical analysis of data collected before wheat is separated from that of data collected after wheat). 
ed at the lower layer of the A-C soil. In contrast with the initial higher amount of available $\mathrm{P}_{-} \mathrm{PO}_{4}$ and $\mathrm{S}-\mathrm{SO}_{4}$, the A-C soil showed a significant lower level of $\mathrm{AmP}$ and $\mathrm{ArS}$ activity.

\section{Influence on plant-root system and growth of durum wheat}

The first primary roots were characterised by a thinner diameter in the P-C than in the A-C soil (Figure 2A). The seasonal root growth monitored throughout rhizotron windows showed a sharp increase in root elongation in mid-March (Figure 2B) coinciding with the active growth of the culm as found in Klepper et al. (1984). A faster elongation rate was observed in the P-C soil, and the differences became significant in mid-April (Figure 2B). In the $\mathrm{P}-\mathrm{C}$ soil, the faster elongation of the roots occurred, together with a greater number of root tips (Figure 3), brought to a higher root density on the topsoil layers (Figure 4). The observation throughout the rhizotrons also allowed us to evidence a different topographical distribution of roots in the two cropping systems as a significantly greater number of root tips was recorded at $10-20 \mathrm{~cm}$ in the P-C soil (Figure 3). Overall, the number of root tips tended to decrease at lower depth in both the cropping systems, but a sharper decrease was observed in the P-C than in the A-C soil (Figure 3). Despite the different morphology and distribution of roots, the root metabolic activity did not significantly differ between the P-C and A-C soil. In contrast, the SPAD index and the canopy metabolism, quantified in terms of photosynthetic activity, were found to be significantly higher for wheat plants cropped in the P-C than in the AC soil (Table 4).

Behind an equal number of ears growth per square meter, all the agronomic data were significantly higher in the $\mathrm{P}-\mathrm{C}$ than in the A-C soil, especially in regard to the number of fertile spikelets per ear, caryopsis per ear and final yield, which almost doubled in the P-C soil (Table 4).

\section{Discussion}

\section{Soil organic carbon dynamics, soil biochemical activity and nutrients availability}

The accumulation of organic carbon substantially differed in the organically farmed soil after 13 years of $\mathrm{P}-\mathrm{C}$ and $\mathrm{A}-\mathrm{C}$ crop rotations (Figure 1). With particular regard to the upper soil layer, the P-C crop rotation allowed for the highest gain of SOC and of all the investigated organic fractions.
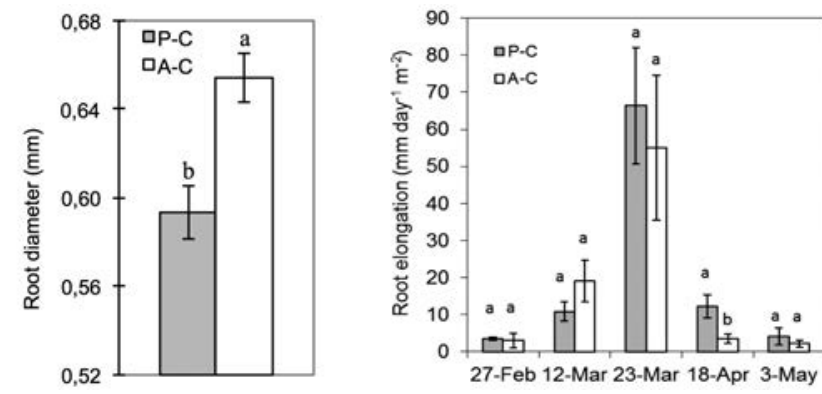

Figure 2. Diameter of primary roots on 96 plants per treatment and daily primary root elongation of roots visible on the rhizotron window $\left(\mathrm{mm} \mathrm{d}^{-1} \mathrm{~m}^{-2}\right)$ of durum wheat in alfalfa-crop rotation and annual crop rotation soils. Different letters denote significant differences (Student's $t$ test $\mathbf{P}<0.05)$ of the mean $( \pm$ standard deviation).

Table 3. Soil biochemical properties and available nitrogen, phosphorus and sulphur in the alfalfa-crop rotation and annual crop rotation soils, at different depths, before and after cultivation of wheat.

\begin{tabular}{|c|c|c|c|c|c|}
\hline & Sampling depth (cm) & Befor & heat & Afte & leat \\
\hline & & P-C & $\mathrm{A}-\mathrm{C}$ & $\mathrm{P}-\mathrm{C}$ & $\mathrm{A}-\mathrm{C}$ \\
\hline $\mathrm{MBC}\left(\mathrm{mg} \mathrm{C} \mathrm{kg}^{-1}\right)$ & $\begin{array}{l}0-10 \\
10-30\end{array}$ & $\begin{array}{c}359.3( \pm 18.5)^{\mathrm{a}} \\
164.4( \pm 5.0)^{\mathrm{b}}\end{array}$ & $\begin{array}{l}116.4( \pm 1.0)^{\mathrm{c}} \\
102.8( \pm 1.7)^{\mathrm{c}}\end{array}$ & $\begin{array}{l}224.1( \pm 6.2)^{\mathrm{a}} \\
130.6( \pm 5.2)^{\mathrm{b}}\end{array}$ & $\begin{array}{l}98.9( \pm 0.2)^{\mathrm{c}} \\
95.9( \pm 1.4)^{\mathrm{c}}\end{array}$ \\
\hline $\mathrm{dBR}\left(\mathrm{mg} \mathrm{CO} \mathrm{da}^{-1} \mathrm{~g}^{-1}\right)$ & $\begin{array}{l}0-10 \\
10-30\end{array}$ & $\begin{array}{l}128.0( \pm 0.5)^{\mathrm{a}} \\
85.0( \pm 1.0)^{\mathrm{b}}\end{array}$ & $\begin{array}{l}61.3( \pm 1.1)^{\mathrm{c}} \\
60.0( \pm 2.3)^{\mathrm{c}}\end{array}$ & $\begin{array}{l}95.5( \pm 3.5)^{\mathrm{a}} \\
72.6( \pm 1.9)^{\mathrm{b}}\end{array}$ & $\begin{array}{l}67.6( \pm 2.0)^{\mathrm{bc}} \\
62.0( \pm 2.1)^{\mathrm{c}}\end{array}$ \\
\hline$o$-DPO ( $\mu$ moles oxidised catechol g $\left.{ }^{-1} 10 \mathrm{~min}^{-1}\right)$ & $\begin{array}{l}0-10 \\
10-30\end{array}$ & $\begin{array}{l}2.0( \pm 0.0)^{\mathrm{c}} \\
2.1( \pm 0.0)^{\mathrm{b}}\end{array}$ & $\begin{array}{l}2.5( \pm 0.0)^{\mathrm{a}} \\
2.5( \pm 0.0)^{\mathrm{a}}\end{array}$ & $\begin{array}{l}1.7( \pm 0.0)^{\mathrm{c}} \\
1.7( \pm 0.1)^{\mathrm{c}}\end{array}$ & $\begin{array}{l}2.2( \pm 0.0)^{\mathrm{b}} \\
2.1( \pm 0.0)^{\mathrm{a}}\end{array}$ \\
\hline $\operatorname{AmP}\left(\mu \mathrm{g} \mathrm{pNP}^{-1} \mathrm{~g}^{-1}\right)$ & $\begin{array}{l}0-10 \\
10-30\end{array}$ & $\begin{array}{l}311.4( \pm 0.3)^{\mathrm{a}} \\
307.6( \pm 0.4)^{\mathrm{b}}\end{array}$ & $\begin{array}{l}156.6( \pm 1.3)^{\mathrm{c}} \\
141.5( \pm 0.2)^{\mathrm{d}}\end{array}$ & $\begin{array}{l}302.3( \pm 0.6)^{\mathrm{a}} \\
289.9( \pm 0.6)^{\mathrm{b}}\end{array}$ & $\begin{array}{l}177.9( \pm 0.7)^{\mathrm{d}} \\
182.4( \pm 0.5)^{\mathrm{c}}\end{array}$ \\
\hline $\operatorname{ArS}\left(\mu g \mathrm{pNP} \mathrm{h}^{-1} \mathrm{~g}^{-1}\right)$ & $\begin{array}{l}0-10 \\
10-30\end{array}$ & $\begin{array}{l}112.8( \pm 0.4)^{\mathrm{b}} \\
128.5( \pm 0.2)^{\mathrm{a}}\end{array}$ & $\begin{array}{l}51.5( \pm 0.4)^{\mathrm{d}} \\
60.3( \pm 0.3)^{\mathrm{c}}\end{array}$ & $\begin{array}{l}163.8( \pm 0.4)^{\mathrm{a}} \\
124.8( \pm 0.1)^{\mathrm{b}}\end{array}$ & $\begin{array}{l}56.9( \pm 0.2)^{\mathrm{d}} \\
71.5( \pm 0.1)^{\mathrm{c}}\end{array}$ \\
\hline $\mathrm{N}-\mathrm{NO}_{3}\left(\mathrm{mg} \mathrm{kg}^{-1}\right)$ & $\begin{array}{l}0-10 \\
10-30\end{array}$ & $\begin{array}{l}264.5( \pm 19.7)^{\mathrm{a}} \\
149.5( \pm 14.6)^{\mathrm{b}}\end{array}$ & $\begin{array}{c}42.5( \pm 20.4)^{\mathrm{c}} \\
45.5( \pm 9.2)^{\mathrm{c}}\end{array}$ & $\begin{array}{l}57.8( \pm 5.0)^{\mathrm{a}} \\
59.8( \pm 4.2)^{\mathrm{a}}\end{array}$ & $\begin{array}{l}19.8( \pm 7.9)^{b} \\
14.1( \pm 2.0)^{b}\end{array}$ \\
\hline $\mathrm{P}_{\mathrm{ols}}\left(\mathrm{mg} \mathrm{kg}^{-1}\right)$ & $\begin{array}{l}0-10 \\
10-30\end{array}$ & $\begin{array}{l}15.9( \pm 0.1)^{\mathrm{c}} \\
15.2( \pm 0.0)^{\mathrm{d}}\end{array}$ & $\begin{array}{l}19.9( \pm 0.1)^{\mathrm{b}} \\
21.2( \pm 0.1)^{\mathrm{a}}\end{array}$ & $\begin{array}{l}9.48( \pm 0.2)^{b} \\
9.79( \pm 0.1)^{b}\end{array}$ & $\begin{array}{c}12.46( \pm 0.1)^{\mathrm{a}} \\
8.8( \pm 0.2)^{\mathrm{c}}\end{array}$ \\
\hline $\mathrm{S}_{-} \mathrm{SO}_{4}\left(\mathrm{mg} \mathrm{kg}^{-1}\right)$ & $\begin{array}{l}0-10 \\
10-30\end{array}$ & $\begin{array}{l}23.4( \pm 0.3)^{\mathrm{b}} \\
14.5( \pm 1.1)^{\mathrm{c}}\end{array}$ & $\begin{array}{l}26.9( \pm 1.7)^{\mathrm{a}} \\
22.0( \pm 0.8)^{\mathrm{b}}\end{array}$ & $\begin{array}{l}15.1( \pm 1.2)^{\mathrm{a}} \\
17.3( \pm 2.0)^{\mathrm{a}}\end{array}$ & $\begin{array}{l}12.4( \pm 1.2)^{b} \\
\text { nd }\end{array}$ \\
\hline
\end{tabular}

P-C, alfalfa-crop rotation; A-C, annual crop rotation; MBC, microbial biomass carbon; dBR, basal respiration; o-DPO, orto-diphenoloxidase; AmP, alkaline phosphatase; ArS, arylsulfatase. a-dDifferent letters denote significant differences (Tukey's HSD test $\mathrm{P}<0.05$ ) of the mean values ( \pm standard deviation) between $\mathrm{P}-\mathrm{C}$ and $\mathrm{A}-\mathrm{C}$ soils due to crop rotation $\mathrm{x}$ depth interaction, within each sampling period (statistical analysis of data collected before wheat is separated from that of data collected after wheat). nd, not detected. 
The P-C crop rotation was more efficient in leaving a larger amount of residues that turned out to be a very large amount of LFOM. Indeed, previous studies have showed that LFOM increases under crop rotation including alfalfa and with the number of alfalfa growing years (Wang et al., 2009; Zhang et al., 2009).

This high accumulation of LFOM may have led to the greater amount of SOC observed in the P-C soil in comparison to that in the A-C soil. Nevertheless, the role of LFOM in building SOC is still controversial. In fact, some studies have reported that particulate organic matter, both free and occluded, is not an early indicator for SOC changes (Leifield and Kogel Kabner, 2005), and some others state that LFOM is a sensitive parameter of SOC variation (Tan et al., 2007).

In our study, the highest amount of SOC was measured in the presence of the highest amount of LFOM (Figure 1). It has to be pointed out that, especially in the P-C soil, LFOM appeared to be the most sensitive fraction as it diminished by about $84 \%$ (on average between depths) after wheat cultivation. Nonetheless, SOC reduced to a minor extent (30\%) (on average between depths) and remained significantly higher in the $\mathrm{P}-\mathrm{C}$ than in the A-C soil.

These findings suggest that LFOM plays a key role in the build up of SOC in organically managed soils. Indeed, despite the highest distribution of organic amendments (Table 1) in the A-C soil, the build up of organic carbon was far lower than that in the P-C crop system.

In order to understand the dynamics that regulate the balance of organic carbon in soil, the relative abundance of soluble and humic fraction to SOC was estimated (Table 2). In contrast with the A-C soil, which tended to be relatively more abundant in soluble organic carbon, the P-C soil was initially relatively richer in terms of humic fraction.

This different trend may be due to a different microbial utilisation of the available carbon sources. In the P-C soil, the presence of perennial legume may have favoured the continuous supply of the more accessible pools of organic carbon, i.e., LFOM and WSOC which, coupled with a higher availability of N, might have preferentially led soil microorganisms to degrade the more labile carbon instead of ligneous recalcitrant carbon, thus enhancing soil in humic fraction (Leitner et al., 2012). Indeed, in our study, the P$\mathrm{C}$ soil always showed lower $o$-DPO activity than that in the A-C soil (Table 3). As already known, oxidative enzyme activities mediate for the degradation and neo-genesis of recalcitrant organic carbon in soil, being closely involved in the carbon cycle (Burns et

Table 4. Root and canopy metabolic activity, yield and yield quality of wheat cropped in alfalfa-crop rotation and annual crop rotation soils.

\begin{tabular}{|c|c|c|}
\hline & P-C & $\mathrm{A}-\mathrm{C}$ \\
\hline Root respiration $\left(\mu \mathrm{mol} \mathrm{g}{ }^{-1} \mathrm{~s}^{-1}\right)$ & $0.4( \pm 0.08)^{\mathrm{a}}$ & $0.5( \pm 0.05)^{\mathrm{a}}$ \\
\hline Photosyntesis $\left(\mu \mathrm{mol} \mathrm{m}{ }^{-2} \mathrm{~s}^{-1}\right)$ & $33.8( \pm 1.4)^{\mathrm{a}}$ & $7.8( \pm 0.96)^{\mathrm{b}}$ \\
\hline SPAD-index & $50.7( \pm 3.12)^{\mathrm{a}}$ & $13.2( \pm 3.9)^{\mathrm{b}}$ \\
\hline Ears $\mathrm{m}^{-2}$ & $395.0( \pm 18.6)^{\mathrm{a}}$ & $398.0( \pm 30.8)^{\mathrm{a}}$ \\
\hline Fertile spikelet ear $^{-1}$ & $13.4( \pm 0.93)^{\mathrm{a}}$ & $9.2( \pm 0.42)^{\mathrm{b}}$ \\
\hline Caryopsis ear $^{-1}$ & $23.1( \pm 3.87)^{\mathrm{a}}$ & $12.0( \pm 1.64)^{b}$ \\
\hline Protein (\%) & $13.1( \pm 0.24)^{\mathrm{a}}$ & $9.6( \pm 0.31)^{\mathrm{b}}$ \\
\hline Yield $\left(\mathrm{t} \mathrm{Ha}{ }^{-1}\right)$ & $4.1( \pm 0.64)^{\mathrm{a}}$ & $1.9( \pm 0.21)^{\mathrm{b}}$ \\
\hline
\end{tabular}

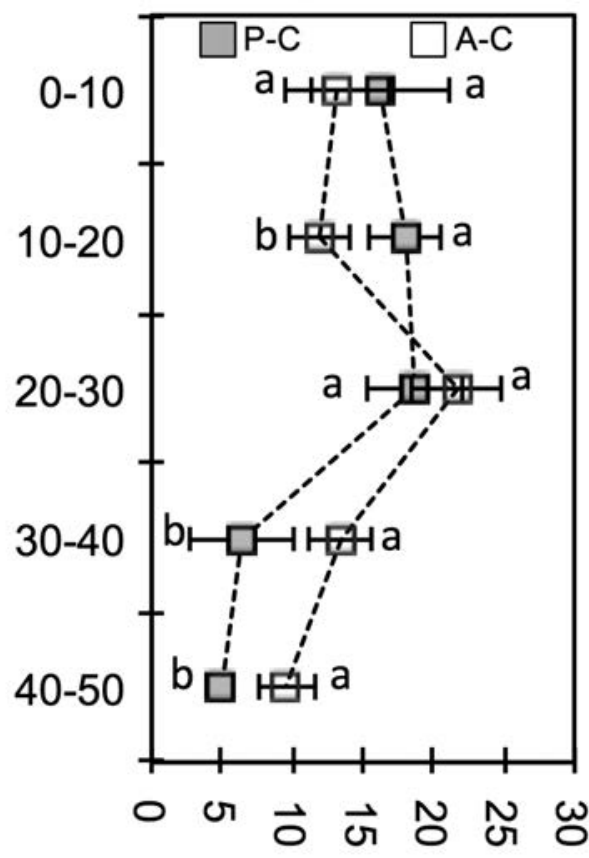

tips $\left(\mathrm{n} \mathrm{m}^{-2}\right)$

Figure 3. Number of root tips per $\mathrm{m}^{2}$ recorded on rhizotron over 5 soil profile depths. Different letters denote significant differences (Tukey's honest significant difference and Student's t test $\mathbf{P}<0.05)$ of the mean $( \pm$ standard deviation).

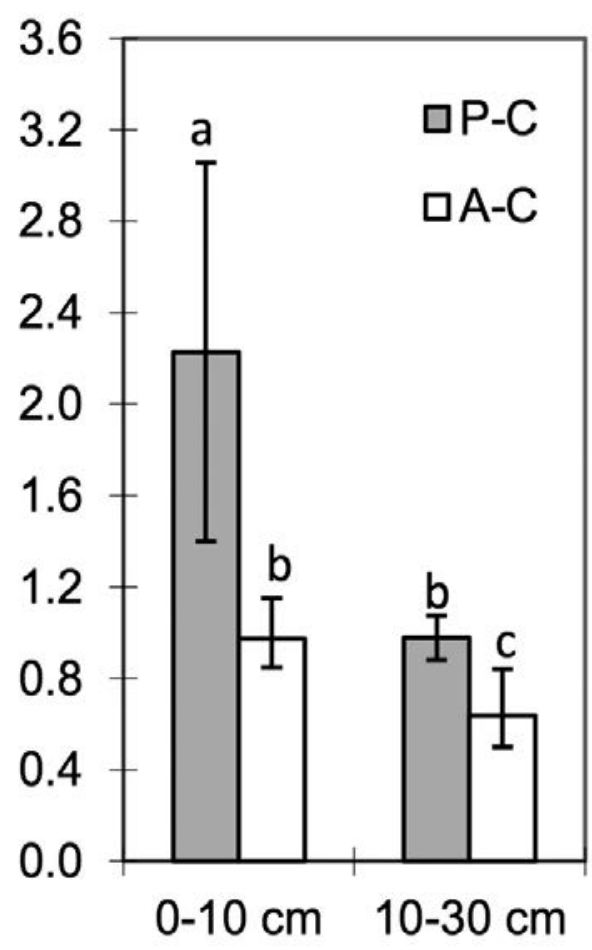

Figure 4. Root weight density expressed as $\mathrm{mg}$ root $/$ soil $\mathrm{cm}^{-3}$. Different letters denote significant differences (Tukey's honest significant difference and Student's $t$ test $P<0.05$ ) of the mean ( \pm standard deviation). 
al., 2013). The higher level of phenol-oxidase activity in the A-C soil may have come from the lower amount of the labile $\mathrm{C}$ fraction. This fact could have led the soil microorganisms to degrade recalcitrant $\mathrm{C}$ fraction and to a less accumulation of humic substances.

In accordance with other studies (Bongiovanni and Lobartini, 2006), the cultivation of wheat had an overall detrimental effect on all of the organic $\mathrm{C}$ pools examined. The major depletion observed at $0-10 \mathrm{~cm}$ of the P-C soil was likely due to higher microbial biomass content and activity coupled with greater availability of $\mathrm{N}$ (Leitner et al., 2012; Zotarelli et al., 2012).

In contrast with $\mathrm{N}$, the $\mathrm{P}-\mathrm{C}$ soil contained an initial lower amount of available phosphorus and sulphur than that in the A-C soil. Nonetheless, compared to the A-C soil, the availability of these nutrients was found to slightly increase in the P-C soil after the cultivation of wheat (Table 3). Given the lower level of AmP and ArS activities, responsible for the biochemical release of organic phosphorus and sulphur, the initial higher amount of these elements observed in the A-C soil could likely be due to the more frequent application of organic fertilisers (Table 1). In contrast, the less initial availability of these nutrients in the P-C soil could likely be due to the alfalfa root uptake.

Finally, it has to be underlined that despite the overall detrimental effect caused by the cultivation of wheat, the P-C soil was mostly able to preserve a higher level of residual fertility than that in the A-C soil in terms of organic carbon pools accrued, biochemical activities and nutrient availability.

\section{Plant root development and growth}

Root formation represents a substantial metabolic cost to plant (Adams et al., 2013), and it can lead to yield penalty if the plant is forced to sustain a massive root apparatus that indiscriminately explores soil profile without having any nutritional profit. Beyond the genotypic characters, the root morphology and exploring capacity are markedly affected by the physical and chemical conditions of the soil (Hoad et al., 2001). In our field experience, differences in root morphology were already evident at the seedling state of wheat similarly with what found by Ito et al. (2006) in the presence of different soil physical fertility. The P-C weaker soil favoured the formation of thinner seminal roots than that measured in the A-C strong soil, as previously found by Goodman and Ennos (1999) in maize and sunflower, due to the need for the root to apply a stronger mechanical strength for soil penetration (Materechera et al., 1992). Given the presence of the same textured soil, equally tilled before planting wheat, this behaviour can be attributed to lower mechanical impedance in the $\mathrm{P}-\mathrm{C}$ soil possibly induced by lower soil bulk density and the major accumulation of SOC. Moreover, in the P-C soil, the previous presence of the vigorous alfalfa root system may have operated a sort of biological drilling in the soil, and as a result, traced preferential soil paths throughout the wheat roots may have advantageously been developed (Chen and Weil, 2011). In fact, afterwards, it was observed that root axis growth further in the $\mathrm{P}-\mathrm{C}$ soil than in the A-C soil; thus positively influencing productivity, since longer and thinner roots are phenotypic characters associated with increased root efficiency (Eissenstat, 1992).

In the P-C soil, the above characteristics were also associated with a higher number of primary axis radical tips, a faster daily growth rate and an overall higher root density. Many factors could have led to the different behaviour of the roots observed in the P$\mathrm{C}$ and A-C soils. The different root morphology may have been a result of the presence of a major amount of $\mathrm{N}$ available in the $\mathrm{P}-\mathrm{C}$ soil as it has been reported that, in several taxa, the morphogenesis of root may respond to the availability of $\mathrm{N}$ (Mi et al., 2010).
Indeed, despite a general increase of root density in the top layer consistent with Morita and Abe's (1996) findings, the observation of rhizotrons revealed a different topographical distribution of roots since a greater part of the wheat root apparatus was located superficially in the $\mathrm{P}-\mathrm{C}$ than in A-C soil. The increase in rooting density in the upper layer of the P-C soil could be a plant strategy to improve the uptake of nitrate, which, as a very mobile ion, may easily escape a lower density root system by leaching deeply in soil (Dunbabin et al., 2003). The higher amount of humic substances in the upper layer of the P-C soil may also have favoured the major root density observed. Indeed, these molecules are widely studied and considered to be root growth promoters by acting as morphogenic compounds which are able to modulate for meristematic cell activity and the hyperinduction of sites of lateral root emergence (Canellas et al., 2012).

Despite the observed morphogenetic differences, root respiration activity did not differ between the P-C and A-C soils, thus indicating lack of physiological stress, generally indicated by a metabolic reduction, in both soils.

In contrast, a significantly higher level of chlorophyll content and photosynthetic activity were found for wheat plants cultivated in P-C soil and were most likely supported by their larger root system and the major uptake of nutrients. These results show that the P-C soil had physico-chemical properties that were highly favourable to the better adaptation and development of the wheat root system that produced a greater number of fertile spikelets, caryopsis per ear and almost doubled the yield.

\section{Conclusions}

Organic farming relies on the restoration of soil organic matter and biochemical-mediated process for the natural release of nutrients in order to sustain crop production. Nonetheless, its effectiveness in building the fertility of arable soils strictly depends on the agronomical strategy adopted. The present trial refers to a single year and for this reason it can only be considered as a preliminary observations. Nevertheless, the two cropping systems tested here brought substantial differences in the amount of cumulated organic carbon, available nutrients and soil metabolic activity and induced conditions for a different adaptation and development of the root plant-system and yield of durum wheat. The $\mathrm{P}-\mathrm{C}$ was able to store a higher amount of organic carbon in terms of both labile and humic fractions and a higher level of biochemical activity than AC. The cultivation of wheat had an overall detrimental effect on both soils, but the P-C soil had the capacity to be more resilient and preserved a higher level of residual fertility than the A-C soil. Overall, the P-C soil induced the formation of thinner and longer radical apparatus associated with higher root density, which is an important phenotypic character to maximise the exploring ability and foraging efficiency of roots. Finally, compared to the A-C soil, the photosynthetic activity of wheat and the number of fertile spikelets and caryopses per ear increased in the P-C soil leading to double the yield.

\section{References}

Adams TS, McCormack ML, Eissenstat DM, 2013. Foraging strategies in trees of different root morphology: the role of root lifespan. Tree Physiol. 33:940-8. 
ASSAM, 2013. Agenzia Servizi Settore Agroalimentari delle Marche - Servizio Agrometeo Regionale. Available from: http://meteo.regione.marche.it

Bengough AG, Castrignano A, Pages L, van Noordwijk M, 2000. Sampling strategies, scaling, and statistics. In: A.L. Smit, A.G. Bengough, C. Engels, M. van Noordwijk, S. Pellerin, S.C. van de Geijn (eds.) Root methods. Springer, Berlin, Germany, pp. 147-73.

Bongiovanni MD, Lobartini JC, 2006. Particulate organic matter, carbohydrate, humic acid contents in soil macro-and microaggregates as affected by cultivation. Geoderma 136:660-5.

Burns RG, DeForest JL, Marxsen J, Sinsabaugh RL, Stromberger ME, Wallenstein MD, Weintraub MN, Zoppini A, 2013. Soil enzymes in a changing environment: Current knowledge and future directions. Soil Biol. Biochem. 58:216-34.

Canellas PL, Dobbss, LB, Oliveira AL, Chagas JG, Aguiar NO, Rumjanek VM, Novotny EH, Olivares FL, Spaccini R, Piccolo A, 2012. Chemical properties of humic matter as related to induction of plant lateral roots. Eur. J. Soil Sci. 63:315-24.

Chen G, Weil RR, 2011. Root growth and yield maize as affected by soil compaction and cover crops. Soil Till. Res. 117:17-27.

Cookson WR, Murphy DV, Roper MM, 2008. Characterizing the relationships between soil properties and microbial function and composition along a tillage disturbance gradient. Soil Biol. Biochem. 40:763-77.

Dauer JM, Withington JM, Oleksyn J, Chorover J, Chadwick OA, Reich PB, Eissenstat DM, 2009. A scanner-based approach to soil profile-wall mapping of root distribution. Dendrobiology 62:35-40.

Domínguez A, Bedano JC, Becker AR, Arolfo-Dominguez RV, 2013. Organic farming fosters agroecosystem in Argentinian temperate soils: Evidence from litter decomposition and soil fauna. Appl. Soil Ecol. 83:170-6.

Dumontet S, Mathur, SP, 1989. Evaluation of respiration-based methods for measuring microbial biomass in metal-contaminated acidic mineral and organic soils. Soil Biol. Biochem. 21:431-6.

Dunbabin V, Diggle A, Rengel, Z, 2003. Is there an optimal root architecture for nitrate capture in leaching environments? Plant Cell Environ. 26:835-44.

Eissenstat DM, 1992. Cost and benefits of constructing root of small diameter. J. Plant Nutr. 15:763-82.

Eivazi F, Tabatabai MA, 1977. Phosphatases in soils. Soil Biol. Biochem. 9:167-72.

García-Orenes F, Roldan A, Mataix-Solera J, Cerdà A, Campoy M, Arcenegui V, Caravaca F, 2012. Soil structural stability and erosion rates influenced by agricultural management practices in a semi-arid Mediterranean agro-ecosystem. Soil Use Manage. 28:571-9.

Goodman AM, Ennos AR, 1999. The effects of soil bulk density on the morphology and anchorage mechanics of the root systems of sunflower and maize. Ann Bot. 83:293-302.

Henriksen TM, Breland T, 1999. Nitrogen availability effects on carbon mineralization fungal and bacterial growth, and enzyme activities during decomposition of wheat straw in soil. Soil Biol. Biochem. 31:1121-34.

Hoad SP, Russell G, Lucas ME, Bingham IJ, 2001.The management of wheat, barley, and oat root systems. Adv. Agron. 74:193-246.

Jackson RB, Canadell J, Ehleringer, JR, Mooney HA, Sala OE, Schulze, ED, 1996. A global analysis of root distributions for terrestrial biomes. Oecology 108:389-411.

Joffre R, Ågren GI, Gillon D, Bosatta E, 2001. Organic matter quality in ecological studies: theory meets experiment. Oikos 93:451-8.

Khan NA, Samiullah Singh S, Nazar R, 2007. Activities of Antioxidative Enzymes, Sulphur Assimilation, Photosynthetic Activity and Growth of Wheat (Triticum aestivum) Cultivars Differing in Yield Potential Under Cadmium Stress. J. Agr. Crop Sci. 193:435-44.

Klepper B, Belford RK, Rickman RW, 1984. Root and shoot development in winter wheat. Agron. J. 76:117-22.

Ito K, Tanakamaru K, Morita S, Abe J, Inanaga S, 2006. Lateral root development, including responses to soil drying, of maize (Zea mays) and wheat (Triticum aestivum) seminal roots. Physiol. Plant. 127:260-7.

Leifeld J, 2012. How sustainable is organic farming? Agr. Ecosyst. Environ. 150:121-2.

Leifeld J, Kögel-Knabner I, 2005. Soil organic matter fractions as early indicators for carbon stocks changes under different land use? Geoderma 124:143-55.

Leitner S, Wanek W, Wild B, Haemmerle I, Kohl L, Keiblinger KM, Zechmeister-Boltenstern S, Richter A, 2012. Influence of litter chemistry and stoichiometry on glucan depolymerisation during decomposition of beech (Fagus sylvatica L.) litter. Soil Biol. Biochem. 50:174-87.

Lipiec J, Horn R, Pietrusiewicz J, Siczek A, 2012. Effect of soil compaction on root elongation and anatomy of different cereal plant species. Soil Till. Res. 121:74-81.

López-Bucio J, Cruz-Ramirez A, Herrera-Estrella L, 2003. The role of nutrient availability in regulating root architecture. Curr. Opin. Plant Biol. 6:280-7.

Marinari S, Mancinelli R, Campiglia E, Grego S, 2006. Chemical and biological indicators of soil quality in organic and conventional farming systems in Central Italy. Ecol. Indic. 6:701-11.

Markwell J, Osterman JC, Mitchell JL, 1995. Calibration of the Minolta SPAD-502 leaf chlorophyll meter. Photosynth. Res. 46:467-72.

Materechera SA, Alston AM, Kirby JM, Dexter AR, 1992. Influence of root diameter on the penetration of seminal roots into a compacted subsoil. Plant Soil 144:297.

Mi G, Chen F, Wu Q, Lai N, Yuan L, Zhang F, 2010. Ideotype root architecture for efficient nitrogen acquisition by maize in intensive cropping systems. Sci. China Life Sci. 53:1369-73.

Morita S, Abe J, 1996. Development of root systems in wheatand rice. In: O. Ito, C. Johansen, J.J. Adu-Gyamfi, K. Katayama, J.V.D. Kumar Rao, T.J. Rego (eds.) Roots and nitrogen in cropping systems of the semi-arid tropics. Japan International Research Center for Agricultural Sciences, Tokyo, Japan, pp. 185-98.

Paetz A, Wilke BM, 2005. Soil sampling and storage. In: R. Margesin, F. Schinner (eds.) Soil biology, manual for soil analysis. Springer-Verlag, Berlin, Germany. pp. 1-45.

Panagos P, Hiederer R, Van Liedekerke M, Bampa F, 2013. Estimating soil carbon in Europe based on data collected through an European network. Eco. Indic. 24:439-50.

Parras-Alcántara L, Díaz-Jaimes L, Lozano-García B, Fernández Rebollo P, Elcure FM, Carbonero Muñoz MD, 2014. Organic farming has little effect on carbon stock in a Mediterranean dehesa (southern Spain). Catena 113:9-17.

Perucci P, Casucci C, Dumontet S, 2000. An improved method to evaluate o-diphenol oxidase activity of soil. Soil Biol. Biochem. 32:1927-33.

Romanyà $\mathrm{J}$, Rovira $\mathrm{P}, 2011$. An appraisal of soil organic $\mathrm{C}$ content in Mediterranean agricultural soils. Soil Use Manage. 27:321-32.

Sainju UM, Lenssen AW, Caesar-TonThat T, Jabro JD, Lartey LT, 
Evans, RG, Allen BL, 2011. Dryland residue and soil organic matter as influenced by tillage, crop rotation, and cultural practice. Plant Soil. 338:27-41.

Santos VB, Araújo ASF, Leite LFC, Nunes LAPL, Melo WJ, 2012. Soil microbial biomass and organic matter fractions during transition from conventional to organic farming systems. Geoderma 170:227-131.

Stockdale EA, Shepherd MA, Fortune S, Cuttle SP, 2002. Soil fertility in organic farming systems-fundamentally different? Soil Use Manage. 18:301-8.

Tabatabai MA, Bremner JM, 1970. Arylsulfatase activity of soils. Soil Sci. Soc. Am. J. 34:225-9.

Tan Z, Lal R, Owens L, Izaurralde RC, 2007. Distribution of light and heavy fractions of soil organic carbon as related to land use and tillage practice. Soil Till. Res. 92:53-9.

Vance ED, Brooks PC, Jenkinson DS, 1987. An extraction method for measuring soil microbial biomass C. Soil Biol. Biochem. 19:703-7.

Vogt KA, Vogt DJ, Bloomfield J, 1998. Analysis of some direct and indirect methods for estimating root biomass and production of forests at an ecosystem level. Plant Soil 200:71-89. von Lützow M, Kögel-Knabner I, Ekschmitt K, Flessa H, Guggenberger G, Matznere E, Marschnerf B, 2007. SOM fractionation methods: Relevance to functional pools and to stabilization methods. Soil Biol. Biochem. 39:2183-207.

Wang XL, Jia Y, Li XG, Long RJ, Ma Q, Li FM, Song YJ, 2009. Effects of land use on soil total and light fraction organic, and microbial biomass $\mathrm{C}$ and $\mathrm{N}$ in a semi-arid ecosystem of northwest China. Geoderma 153:285-90.

Wilke BM, 2005. Determination of chemical and physical soil properties. In: R. Margesin, F. Schinner (eds.) Soil biology, manual for soil analysis. Springer-Verlag Berlin Heidelberg, pp 47-9.

Zhang T, Wang Y, Wang X, Wang Q, Han J, 2009. Organic carbon and nitrogen stocks in reed meadow soils converted to alfalfa fields. Soil Till. Res. 105:143-8.

Zotarelli L, Zatorrea NP, Boddey RM, Urquiaga S, Jantalia CP, Franchini JC, Alves BJR, 2012. Influence of no-tillage and frequency of a green manure legume in crop rotations for balancing $\mathrm{N}$ outputs and preserving soil organic $\mathrm{C}$ stocks. Field Crop. Res. 132:185-95. 